\title{
Dull Compulsion or Perceived Legitimacy? Assessing Why People Comply with the Law in Nigeria
}

\author{
Akinlabi, Oluwagbenga Michael* \\ Murphy, Kristina
}

Do people living in societies rife with police corruption comply with the law because they perceive police as legitimate or because of their feelings of endemic powerlessness (i.e., what Tankebe (2009) refers to as dull compulsion)? Prior studies have shown that compliance is driven primarily by perceptions that authorities and their laws are legitimate and entitled to be obeyed. Using cross-sectional survey data collected from Southwest Nigeria, this study found that perceptions of police effectiveness and procedural justice were related to Nigerians' self-reported compliance with the law. Importantly, and unexpectedly, neither dull compulsion nor perceptions of police legitimacy were related to Nigerians' self-reported compliance behaviour. The implications of these findings for policing in postcolonial African societies are discussed.

Keywords procedural justice, police effectiveness, police corruption, police legitimacy, dull compulsion, compliance with the law

*Corresponding author. School of Behavioural Cognitive and Social Sciences, University of New England, Australia

This paper is a special issue on procedural justice being edited by Edward Maguire of Arizona State University. The paper should be finalised and published before January 2018. 


\section{INTRODUCTION}

A large body of evidence from the procedural justice literature suggests that people ascribe legitimacy to authorities when authorities treat their citizens with procedural justice. This same body of literature also suggests that people comply with laws when they view authorities as legitimate (Jackson et al., 2012; Murphy, Bradford, \& Jackson, 2015; Reisig, Tankebe, \& Mesko, 2014; Tom R. Tyler, 1990; Tom R Tyler, 1997; Tom R. Tyler, 2006). Do Nigerians comply with the law because they perceive the police, the visible enforcers of the law, as legitimate? Or do they comply with the law due to feelings of endemic powerlessness and resignation (i.e., what we will refer to as dull compulsion)? And how do Nigerians ascribe legitimacy to their police?

Recent studies conducted in Africa have shown that people's motivation to comply with the law may not always be due to their perceived legitimacy of legal authorities. This same research demonstrates that legitimacy may not be fostered by perceived procedural fairness. Some researchers have argued that in these settings, compliance behaviour may be based rather on prudential calculations or social habits that are founded on feelings of endemic powerlessness and resignation (Akinlabi, 2016; Carrabine, 2005; Tankebe, 2009, 2013). For example, Tankebe (2009) has argued that in post-colonial societies where police abuse and corruption is endemic, the public's obligation to view police as legitimate or their willingness to comply with the law is unlikely to be explained by citizens viewing the police as procedurally fair or legitimate. Instead people tend to comply with laws out of a sense of 'dull compulsion'. Tankebe argues that dull compulsion may become apparent in situations where citizens believe they are powerless to fight police abuse and as a result comply with the law in a bid to avoid police reprisals. That is, they comply not necessarily because they feel legal authorities are legitimate but because of fear, which can lead to pseudo conformity (see Carrabine 2005 for a similar argument in prison systems). Though Carrabine and Tankebe's arguments seem 
plausible it should be noted that dull compulsion was never measured or empirically tested in their studies. As such, they do not represent relevant empirical evidence to substantiate the importance of dull compulsion as a precursor to compliance with the law.

The current study presents an important first attempt to empirically test and understand the relevance of dull compulsion as a major explanation for why people comply with the law in postcolonial, dictatorial, and socially polarised societies. Consequently, one of the main aims of this paper is to examine the relationship between perceived police legitimacy and expressed feelings of dull compulsion on self-reported willingness to comply with the law in Nigeria. We also examine whether in a country like Nigeria, antecedent variables such as procedural justice and police effectiveness, as well as experiences of police abuse, police corruption, predatory policing are associated with perceptions of police legitimacy, dull compulsion, and selfreported compliance with the law. Before presenting the findings, however, this paper first proceeds with a review of relevant literature. Specifically, a history of policing in Nigeria will be discussed, followed by a brief review of the procedural justice and police legitimacy literature. This will be followed by a brief overview of how the current study extends the work of previous studies in the field and sets out its aims and objectives.

\section{Nigeria in Context: History, Policing, and Popular Discontent}

Before colonisation Nigerians had always policed themselves through local customs, traditions, mores, and values (Davidson, Buah, \& Ade-Ajayi, 1966; Onyeozili, 1998, 2005; Tamuno, 1970). However, after British conquest in 1851 colonial rule was consolidated through a system that undermined the existing traditional informal method of maintaining law and order. The British colonialists introduced new laws, which replaced, or seriously threatened the efficacy of native laws and customs, traditional religions and other sanctions, as well as indigenous tribunals and justice (Carter, 1981; Onoge, 1993; Onyeozili, 2005; Tamuno, 1970). Among the new laws and systems introduced by the colonialists was a pseudo-peelian policing system that 
largely undermined Nigerians' values and dictated behaviour without popular consent (Ahire, 1991; Akinlabi, 2016; Tamuno, 1970).

This first police unit, the Hausa Constabulary, was established in 1861 with 30 exslaves from Sierra Leone (Ahire, 1991). The police were totally alien to the customs and traditional values of the local people and they could not speak the local language (Ahire, 1991; Onoge, 1993; Tamuno, 1970). The Constabulary firmly subjugated the people to British demands (Ahire, 1991). The main focus of the police was to protect the interest of the British Crown by: ensuring the supply of a labour force to construct colonial infrastructures; compelling peasants and farmers to pay colonial taxes; ignoring demands for better working conditions; and promoting several other conditions required for the growth and expansion of the colonial economy (Ahire, 1991; Onoge, 1993; Tamuno, 1970).

During this period, the police were not accountable to the colonised but to the colonisers. The colonial police force behaved ruthlessly; killing, maiming, and looting at the order of the British colonialists. As the people had no control over the plethora of police abuse and arbitrariness, some devised means to avoid contact with the police, some agitated for a reversal to the pre-colonial system, and some fatalistically conformed to police demands (Ahire, 1991; Alemika, 1993; Onoge, 1993; Otu, 1999).

In 1960, Nigeria declared its independence from British colonial rule. Unfortunately, the newly constituted government had a vested interest in maintaining the status quo. The police force became the instrument of political oppression, deployed for the brutalisation and intimidation of party antagonists and political oppressions (Ahire, 1993; Ohonbamu, 1972; Tamuno, 1970; Vaaseh \& Ehinmore, 2011). The members of the local police forces were poorly trained and comprised mostly unqualified people; party thugs, political sympathisers, and several others who were selected by shoddy means (Ohonbamu, 1972; Vaaseh \& 
Ehinmore, 2011). Post-independent leaders and successive government administration in Nigeria failed to deliver on their promises to reform the police and/or to bring about "public goods" in policing as expected by the citizens.

Recent studies have also confirmed the perpetuation of colonial legacies in Nigerian policing in the $21^{\text {st }}$ century (see Akinlabi, 2016; Alemika, 2010; Okafor, 2007; Oluwaniyi, 2011; Onoge, 1993). The relationship between the police and the people continues to be troublesome. Public order maintenance is often achieved at a great cost; mostly through harassment and intimidation. The police have an impressive profile of abuse and ruthless oppression of citizens (Agbiboa, 2015; Akinlabi, 2016). They have been accused of arbitrary arrests, violence, brutality, extortion, and procedural injustice (Agbiboa, 2015; Akinlabi, 2016; Human Rights Watch, 2010).

\section{Legitimacy, Dull Compulsion and Compliance with the Law}

In recent years, research on police legitimacy and procedural justice policing has increased exponentially (for a review, see Mazerolle et al., 2014). This increase has been predominantly influenced by an increasing understanding that to foster or elicit law-abiding behaviour, the power relations between the police and citizens cannot be predicated solely on deterrence. Instead, the literature has come to accept that law-abiding behaviour must be built on a combination of several normative factors (see Johnson, Maguire, \& Kuhns, 2014; Murphy, Tyler, \& Curtis, 2009; Tom R. Tyler, 1990). Others have argued that legitimacy is essential for authorities to garner compliance and the support of the public (Beetham, 1991; Bradford, Huq, Jackson, \& Roberts, 2014). However, whether legitimacy is viewed the same way or operates similarly in a country like Nigeria is of specific interest and is an important question the current paper seeks to address.

In the West, research has revealed that people are more likely to voluntarily comply 
with the law if they view police as more legitimate (Reisig et al., 2014; Sunshine \& Tyler, 2003). Perceptions of police legitimacy, for the most part, are the agglomeration of public perceptions or experiences of what police do (Tom R. Tyler \& Fagan, 2008). Most notably, Tom Tyler and other policing scholars (Bradford et al., 2014; Hinds \& Murphy, 2007; Sargeant, Murphy, \& Cherney, 2014; Sunshine \& Tyler, 2003; Tom R. Tyler, 2006) suggest that public perceptions of legitimacy are predicated on two main factors: 1) whether police are seen to be treating citizens with procedural justice; and 2) whether police are seen to be effective in their jobs. Procedural justice relates to whether police treat citizens fairly, with respect, act as neutral agents in their decision-making, and provide citizens voice before decisions are made. Police are typically viewed as effective if they can "control crime and criminal behaviour, can create a credible risk of detection and sanction for those who break the law, and can fairly distribute police services across people and communities” (Hinds \& Murphy, 2007, p. 28).

This follows that if what police are mostly known for is abuse of power, corruption and an ineffective ability to control crime, such experiences and/or perceptions will likely have an unpropitious outcome on legitimacy perceptions in the long run. This could erode socially and morally acceptable norms of law. The withdrawal or erosion of norms of law has strong implications for the rejection of a police agency's authority to dictate behaviour or foster compliance with the law (Jackson et al., 2012; Tom R. Tyler, 1990; Tom R Tyler, 1997). Considering that police-public relations in countries such as Nigeria are markedly identified as predatory, abusive, and violent, it is unlikely that police are viewed as legitimate. This begs the question: Will Nigerians then not comply with the law because they do not view their police as legitimate? We suggest they might 'comply' with the law for other reasons.

Although legitimacy has been consistently presented in the policing literature as the key factor responsible for promoting compliance, a new argument has emerged from studies 
conducted in post-colonial societies or in dictatorial regimes. These studies suggest that 'dull compulsion' may be the crucial variable explaining people's compliance behaviour (Tankebe, 2009). For example, Tankebe (2009) argued that compliance with the law might be pointers to some form of dull compulsion - a characteristic of power relations in which subordinates fatalistically accept unfair conditions as unalterable due to a sense of powerlessness (see also, Carrabine, 2004; Tankebe, 2013). Here people comply with laws not because they view police as legitimate, but because they fear police reprisals for doing otherwise.

While no study to date has empirically tested this claim, it has been confirmed empirically that when people have no checks over the arbitrariness of those in authority, they often become fatalistic, avoid trouble by being subservient, or mediate inevitable contacts with bribe offerings (see Alemika, 1993; Baker, 2010; Carrabine, 2004, 2005; Sparks \& Bottoms, 2007; Tankebe, 2013). Hence, the mechanisms and factors important for explaining public attitudes and behaviour toward police and the law in Western democracies is likely to be vastly different to those in dictatorial societies such as Nigeria. It is for this reason that the current study examines how Nigerians come to perceive their police as legitimate, and importantly, to explain why Nigerians comply voluntarily with the law.

\section{The Current Study}

The aims of the current study are twofold. First, it aims to understand the factors associated with Nigerians' perceptions of police legitimacy and their feelings of dull compulsion. Second, it aims to examine whether Nigerians comply with laws voluntarily because they view police as legitimate or because of an endemic sense of powerlessness and fatalistic acquiescence that doing otherwise will be detrimental to their safety (i.e., dull compulsion). 
The study extends prior research in three important ways. First, it is only one of the few studies undertaken testing the relevance and importance of procedural justice, police effectiveness and legitimacy in an African society where police corruption is endemic (see Akinlabi, 2015; Bradford et al., 2014; Tankebe, 2009 for other studies in Africa). Prior research has been contradictory as to the importance of procedural justice for explaining African's perceptions of police legitimacy (see; Akinlabi, 2015 for Nigerian youths; Bradford et al., 2014 for South Africa; Tankebe, 2009 for Ghana). It is therefore important to clarify if procedural justice is important or not to police legitimacy judgements in African countries.

Second, prior studies undertaken in less developed jurisdictions (e.g., Bradford et al., 2014; Johnson et al., 2014; Kochel, 2012; Tankebe, 2009) have included a relatively restricted set of variables when predicting public perceptions of police legitimacy and compliance with the law. A range of attitudinal factors that take into account public perceptions of the corruption and endemic abuse apparent in Nigerian policing will be included in the current study. For example, perceptions of police corruption, predatory policing, experiences of police abuse and views about the legacy of colonial policing are all likely to be important to legitimacy perceptions, feelings of dull compulsion, and subsequent compliance.

Third, and most importantly, the current study extends prior policing scholarship by specifically testing the claim that in dictatorial societies people comply with the law due to dull compulsion not police legitimacy (Tankebe 2009). This assertion has yet to be empirically validated. The current study is the first to do so. 


\section{METHOD}

\section{Data and Participants}

Data for this study were collected through a cross-sectional survey of 600 participants from the South-West geopolitical zone in Nigeria. To draw the sample for this study, two churches, two mosques, and two tertiary institutions were selected at random from each of the six state capitals (i.e., Abeokuta, Ado, Akure, Ibadan, Ikeja, and Oshogbo). Convenience sampling from these institutions was then undertaken. Sampling from cities was based on the fact that police activities and daily encounters with police are more common in capital cities than in rural communities where there is little or no police presence. It is important to note, however, that because the data were collected through a convenience sampling method, caution must be taken not to infer the results of this study to a broader population in Nigeria.

In each of the institutions, permission was sought to survey individuals from either the senior pastor, chief Imam, or the lecturers in charge of the settings. A "captive audience" in each institution was then approached by the first author explaining the purpose of the research and what was required from each participant. Consent forms were handed out to the willing participants and upon reading the consent form, those who were willing to participate were given the survey instrument. A total of 702 people were invited to participate, and 638 indicated a willingness to participate. However, after two weeks of administering the questionnaires, only 611 completed questionnaires were returned. Due to the large amounts of missing data on 11 surveys, only 600 of the returned survey instruments were retained for analysis. The sociodemographic characteristics of the participants are presented in Table 1. 
Table 1 Demographic structure of the sample

\begin{tabular}{|c|c|c|c|c|c|}
\hline Demographics & Range & Percent & & Range & Percent \\
\hline Age & $20-62$ & & Education & & \\
\hline \multirow{5}{*}{$($ Mean $=32.70, \mathrm{SD}=7.52)$} & & & No schooling & & 3.8 \\
\hline & & & Primary & & 1.2 \\
\hline & & & Secondary & & 5.5 \\
\hline & & & University & & 64.3 \\
\hline & & & Postgraduate & & 24.8 \\
\hline Gender & & & Number of children & & $0-7$ \\
\hline Male & & 49.0 & & & \\
\hline Female & & 51.0 & & & \\
\hline Marital status & & & Employment status & & \\
\hline Single & & 45.2 & Unemployed & & 24.5 \\
\hline Married & & 52.7 & Full housewife & & 1.7 \\
\hline \multirow[t]{4}{*}{ Divorced/separated } & & 1.8 & Self employed & & 23.8 \\
\hline & & & Employed full time & & 35.5 \\
\hline & & & Employed part time & & 13.5 \\
\hline & & & Retired & & 0.5 \\
\hline Religion & & & Monthly income (Naira) & & \\
\hline No Religious Affiliation & & 1.8 & $0-5000$ & & 13.8 \\
\hline Muslim & & 19.3 & $6000-10000$ & & 9.5 \\
\hline Catholic & & 7.3 & $11000-20000$ & & 14.7 \\
\hline Protestant/Pentecostal & & 47.2 & $21000-30000$ & & 13.2 \\
\hline Anglican & & 15.3 & $41000-50000$ & & 15.7 \\
\hline Traditional Practice & & 0.3 & $50000-100000$ & & 12.8 \\
\hline \multirow[t]{3}{*}{ Others } & & 8.2 & $100000-200000$ & & 2.3 \\
\hline & & & $300000-400000$ & & 1.3 \\
\hline & & & Above 500000 & & 0.8 \\
\hline \multicolumn{6}{|l|}{ Ethnicity } \\
\hline Yoruba & & 72.0 & & & \\
\hline Hausa & & 10.5 & & & \\
\hline Igbo & & 16.8 & & & \\
\hline
\end{tabular}

Note: US\$1 = 180 Naira

\section{Measures}

The survey contained a total of 50 questions. Unless otherwise noted, all key scales described below were measured on a $1=$ strongly disagree to $5=$ strongly agree Likert scale. The full wordings, showing mean values and standard deviations, are presented in the Table 3.

\section{Compliance with the Law}

Compliance with the law was the key dependent variable in this study. It was measured using a five-item self-report scale adapted from Tom R. Tyler (1990). Questions probed the extent to 
which the respondents act or say they would act within the confines of the law. A higher mean score on this five item scale indicates greater self-reported compliance with the law (Cronbach's $\alpha=.85)$.

\section{Police legitimacy}

Police legitimacy was measured using a five-item scale based on the conceptualisation measured by Murphy, Murphy, and Mearns (2010). It included the beliefs citizens held about the normative appropriateness of police behaviour and their feelings of obligation to obey police. Higher mean scores on the scale indicate greater perceptions of police legitimacy (Cronbach's $\alpha=.86)$.

\section{Dull compulsion}

Drawing from recent arguments raised in literature (i.e., Carrabine, 2005; Tankebe, 2009), a four-item scale was developed by the first author to test dull compulsion in a Nigerian policing context. Items in the dull compulsion scale assessed whether failing to comply with police requests would be detrimental to one's safety. Higher mean scores on the scale indicate stronger feelings of dull compulsion (Cronbach's $\alpha=.85$ )

\section{Procedural justice}

The procedural justice scale was adapted from Tom R. Tyler (2006), Tankebe (2009), and Murphy et al. (2010). The scale has eight items which measured four major components of procedural justice: neutrality, fairness, voice, and respect. A higher mean score on the scale indicated more favourable assessments of procedural justice (Cronbach's $\alpha=.88$ ). This scale assessed general trust in police to use procedural justice, rather than actual experiences of procedural justice during a specific encounter with police. 


\section{Police effectiveness}

Police effectiveness refers to the extent to which police achieve their proper, officially sanctioned duties and goals. This scale was administered using a six-item scale adopted from (Tom R. Tyler, 2006). A higher score on this scale indicated greater perceptions of police effectiveness (Cronbach's $\alpha=.92)$.

\section{Demographic and control variables}

Several additional demographic and control variables were also measured, given past research has indicated that such variables influence public perceptions of police (e.g., Akinlabi, 2015; Akinlabi, 2016; Hinds \& Murphy, 2007; Tom R. Tyler, 2006; Weitzer, 2010). Demographic control variables included: age, gender $($ male $=0$; female $=1)$, marital status (others $=0$; married $=1$ ), education (others $=0$; higher education $=1$ ), religion, and ethnicity (others $=0$; Yoruba majority $=1$ ). The other control variables measured were: predatory policing, police corruption, experience of police abuse, and police colonial origin.

Predatory policing: Predatory policing is best described as policing characterised by selfpreservation and personal enrichment of the police. Predatory policing is mostly seen as the systematic subjugation of subordinate and vulnerable groups by police officers (Gerber \& Mendelson, 2008). The predatory policing scale was constructed using a seven-item scale developed by Akinlabi (2013). A higher score on this scale indicated high prevalence of policing activities that are considered predatory in nature (Cronbach's $\alpha=.90$ ).

Police corruption: Police corruption was measured using a six-item scale adapted from Tankebe (2010), Akinlabi (2011), and Akinlabi (2015). It focused mainly on perceptions rather than actual experiences of police corruption. It incorporated items about bribe taking, extortion, 
and the use of familial connections to influence the police in order to ignore lawlessness or law-breaking behaviour. A higher score on this scale indicated greater perceptions of police corruption (Cronbach's $\alpha=.88$ ).

Experience of police abuse: This scale is a sub-scale of Akinlabi's (2013) police abuse and brutality scale. The subscale measures actual personal experiences of police abuse. Higher scores indicate more experience with police abuse (Cronbach's $\alpha=.79$ ).

Police colonial origin: A police colonial origin scale was developed by the first author using a six-item scale. The scale assessed perceptions about the colonial origin of the police (see Table 3). A higher score indicated more unfavourable assessments of colonial rule (Cronbach's $\alpha=.86)$.

\section{Principal Component Analysis of Constructs}

To confirm the construct validity of all scale measures, each item in the nine scales was subjected to a Principal Component Analysis using varimax rotation (see Table 2). The dimensionality of each scale was maintained with eigenvalues above $1(18.19,11.56,7.49$, $6.21,5.87,4.73,4.10,3.43,2.75)$ and the scree plots confirmed a non-overlapping relationship between each of the nine constructs.

Table 2 Factor Analysis differentiating variables used in the study

\begin{tabular}{|c|c|c|c|c|c|c|c|c|c|}
\hline \multirow[b]{2}{*}{ Items } & \multicolumn{4}{|c|}{ Factors } & \multirow[b]{2}{*}{5} & \multirow[b]{2}{*}{6} & \multirow[b]{2}{*}{7} & \multirow[b]{2}{*}{8} & \multirow[b]{2}{*}{9} \\
\hline & $\mathbf{1}$ & 2 & 3 & 4 & & & & & \\
\hline \multicolumn{10}{|l|}{ Factor 1: Procedural Justice } \\
\hline PJ1 & .66 & & & & & & & & \\
\hline $\mathrm{PJ} 2$ & .71 & & & & & & & & \\
\hline $\mathrm{PJ} 3$ & .71 & & & & & & & & \\
\hline PJ4 & .68 & & & & & & & & \\
\hline PJ5 & .74 & & & & & & & & \\
\hline PJ6 & .76 & & & & & & & & \\
\hline PJ7 & .80 & & & & & & & & \\
\hline PJ8 & .72 & & & & & & & & \\
\hline \multicolumn{10}{|l|}{ Factor 2: Predatory Policing } \\
\hline PRED1 & & .69 & & & & & & & \\
\hline
\end{tabular}




\begin{tabular}{ll}
\hline PRED2 & .79 \\
PRED3 & .78 \\
PRED4 & .79 \\
PRED5 & .83 \\
PRED6 & .73 \\
PRED7 & .72
\end{tabular}

Factor 3: Police Effectiveness

PEF1

PEF2

PEF3 $\quad .77$

PEF4 $\quad .83$

PEF5 $\quad .81$

PEF6 $\quad .78$

Factor 4: Police Corruption

POL_COR1

POL_COR2 $\quad .76$

POL_COR3 $\quad .78$

POL_COR4 $\quad .81$

POL_COR5 $\quad .72$

$\begin{array}{ll}\text { POL_COR6 } & .72\end{array}$

Factor 5: Colonial Origin

COL_ANT1 $\quad .82$

COL_ANT2

COL_ANT3 $\quad .83$

COL_ANT4

COL_ANT5

COL_ANT6 $\quad .72$

Factor 6: Police Legitimacy

PL1

PL2 $\quad .85$

$\begin{array}{ll}\text { PL3 } & .83\end{array}$

$\begin{array}{ll}\text { PL4 } & .81\end{array}$

$\begin{array}{ll}\text { PL5 } & .77\end{array}$

Factor 7: Compliance with the Law

COMP1

\begin{tabular}{lr} 
COMP2 & .80 \\
\hline
\end{tabular}

$\begin{array}{lr}\text { COMP3 } & .82\end{array}$

COMP4 $\quad .83$

Factor 8: Dull Compulsion

DC1

DC2 2

DC3 $\quad$.87

$\begin{array}{ll}\mathrm{DC} 4 & .81\end{array}$

Factor 9: Experience of Police Abuse

EXPAB1

(1)

.71
.71

$\begin{array}{lr}\text { EXPAB3 } & .80\end{array}$

\begin{tabular}{ll} 
EXPAB4 & .69 \\
\hline
\end{tabular}

$\begin{array}{llllllllll}\text { Eigenvalues of } 1 \text { and above explained } & 18.19 & 11.56 & 7.49 & 6.21 & 5.87 & 4.73 & 4.10 & 3.43 & 2.75\end{array}$

The nine components explain a total variance of 64.34 per cent

Kaiser-Meyer-Olkin (KMO) Measure of Sampling Adequacy $=.874$

Bartlett's Test of Sphericity 


$\begin{array}{r}\text { Approx. Chi-Square }=15593.608 \\ \mathrm{df}=1225 \\ \text { sig. }=.000 \\ \text { Extraction Method: Principal Component Analysis. } \\ \text { Rotation Method: Varimax with Kaiser Normalisation } \\ \hline \text { Note: all factor scores }>0.30 \text { are presented }\end{array}$

Note: all factor scores $>0.30$ are presented

\section{RESULTS}

The central aims of this study are to examine the predictors of police legitimacy in Nigeria and to determine whether Nigerians comply with the law due to perceptions of the police as legitimate or due to feelings of dull compulsion. Table 3 shows the mean scores, standard deviations, and the full wordings of the nine scales. Table 4 shows the bi-variate correlations between the scales. Table 5 and 6 present the findings for three multiple regression analyses.

Examining Table 3, the response patterns demonstrate that there is a high expression of dull compulsion, high perceptions of predatory policing, and police corruption. Likewise, Nigerians viewed police as generally ineffective, and perceptions of procedural justice were largely negative. Finally, compliance levels were quite low, indicating respondents were not inclined to voluntarily comply with the law.

Table 3 Means and standard deviation for each variable and scale

\begin{tabular}{|c|c|c|c|}
\hline & Variable items & Mean & SD \\
\hline & Compliance with the Law $($ Mean $=2.09 ; \mathrm{SD}=1.03)$ & & \\
\hline COMP1 & You have bought items or goods even when you knew they were stolen & 2.19 & 1.27 \\
\hline COMP2 & You have used banned substances like marijuana & 2.12 & 1.26 \\
\hline COMP3 & You have driven a car or motorcycle while under the influence of alcohol or other drugs. & 2.04 & 1.20 \\
\hline \multirow[t]{2}{*}{ COMP4 } & You have forged a document or paid someone to do it on your behalf & 2.01 & 1.19 \\
\hline & Police Legitimacy $($ Mean $=2.14 ; \mathrm{SD}=0.91)$ & & \\
\hline PL1 & Even if police are doing the wrong thing, I still feel a moral obligation to obey police & 2.27 & 1.16 \\
\hline PL2 & One should always obey police even if it goes against what you think is right & 2.28 & 1.16 \\
\hline PL3 & My own feelings about what is right and wrong usually agree with police rules and policies & 2.06 & 1.11 \\
\hline PL4 & The police share the same values of ordinary citizens like me & 1.96 & 1.12 \\
\hline \multirow[t]{2}{*}{ PL5 } & People should accept the decisions of police even if they think they are wrong & 2.13 & 1.12 \\
\hline & Dull Compulsion $($ Mean $=3.76 ; \mathrm{SD}=0.98)$ & & \\
\hline DC1 & It is better to obey police than argue with them & 3.79 & 1.14 \\
\hline $\mathrm{DC} 2$ & Police often treat harshly those who argue with them & 3.89 & 1.17 \\
\hline
\end{tabular}




\begin{tabular}{|c|c|c|c|}
\hline \multirow{3}{*}{$\begin{array}{l}\text { DC3 } \\
\text { DC4 }\end{array}$} & Arguing with a police officer is to sign ones' death warrant & 3.52 & 1.26 \\
\hline & If you don't cooperate with police, they will get tough with you & 3.82 & 1.14 \\
\hline & Procedural Justice $($ Mean $=2.50 ;$ SD $=0.92)$ & & \\
\hline PJ1 & If you are treated unfairly by the police, it is easy to get your complaint heard & 2.59 & 1.30 \\
\hline PJ2 & Overall, I am satisfied with how police treat people and handle problems in my community & 2.37 & 1.22 \\
\hline PJ3 & Police treat all people fairly and equally. & 2.20 & 1.20 \\
\hline PJ4 & Police give people the opportunity to express their views before decisions are made & 2.68 & 1.30 \\
\hline PJ5 & Police treat people with dignity and respect & 2.50 & 1.29 \\
\hline PJ6 & Police listen to people before making decisions & 2.70 & 1.29 \\
\hline PJ7 & Police are always polite when dealing with people & 2.39 & 1.16 \\
\hline \multirow[t]{2}{*}{ PJ8 } & Police make decision based upon facts, not their personal biases or opinions & 2.56 & 1.26 \\
\hline & Police Effectiveness $($ Mean $=2.55 ; \mathrm{SD}=1.10)$ & & \\
\hline PEF1 & The police respond promptly to calls about crime & 2.64 & 1.39 \\
\hline PEF2 & The police are always ready to provide satisfactory assistance to victims of crime & 2.50 & 1.26 \\
\hline PEF3 & The police are always able to provide the assistance the public need from them & 2.50 & 1.32 \\
\hline PEF4 & The police are doing well at controlling violent crime & 2.60 & 1.32 \\
\hline PEF5 & Overall, the police are doing a good job in my neighbourhood & 2.55 & 1.29 \\
\hline \multirow[t]{2}{*}{ PEF6 } & When the police stop people they usually handle the situation well & 2.50 & 1.26 \\
\hline & $\begin{array}{l}\text { Experience of Police Abuse }(\text { Mean }=\mathbf{2 . 4 5} ; \mathbf{S D}=\mathbf{0 . 9 8} \text { ) (In the last } 12 \text { months, I have been....) } \\
\text { subjected to harsh treatment by a police officer }\end{array}$ & 2.60 & 1.30 \\
\hline EXPAB2 & tortured by a police officer & 2.21 & 1.17 \\
\hline EXPAB3 & threatened by a police officer & 2.36 & 1.26 \\
\hline \multirow[t]{2}{*}{ EXPAB4 } & forced by the police to do something against my wish & 2.65 & 1.31 \\
\hline & $\begin{array}{l}\text { Predatory Policing }(\text { Mean }=\mathbf{3 . 6 8} ; \mathbf{S D}=\mathbf{0 . 9 4})(\text { The police are known for } \ldots . .) \\
\text { planting evidence or setting up people for offenses they did not commit }\end{array}$ & 3.71 & 1.22 \\
\hline PP2 & shooting innocent citizens & 3.75 & 1.14 \\
\hline PP3 & killing offenders without normal judicial process & 3.63 & 1.16 \\
\hline PP4 & subjecting anyone who disobeys their directives to harsh treatment & 3.74 & 1.18 \\
\hline PP5 & prowling around in the shadows/hidden places so as to arrest people & 3.63 & 1.20 \\
\hline PP6 & stopping people randomly for questioning & 3.51 & 1.23 \\
\hline \multirow[t]{2}{*}{ PP7 } & mounting check-points in order to extort money from citizens & 3.84 & 1.19 \\
\hline & $\begin{array}{l}\text { Police Corruption }(\text { Mean }=3.99 ; \mathbf{S D}=\mathbf{0 . 7 9})(\text { Nigeria Police....) } \\
\text { take bribes }\end{array}$ & 423 & 098 \\
\hline PC2 & is known to deliberately provide false evidence to the courts & 3.90 & 1.04 \\
\hline PC3 & use more force than is legally allowed when making arrests & 4.02 & 0.93 \\
\hline PC4 & are often bribed to overlook unlawful behaviour & 4.03 & 1.02 \\
\hline PC5 & often refuse to investigate, arrest, or prosecute people because they are related to a police officer & 3.83 & 1.03 \\
\hline \multirow[t]{2}{*}{ PC6 } & often refuse to investigate, arrest, or prosecute people because they know influential citizen(s) & 3.94 & 1.03 \\
\hline & Police Colonial Origin $($ Mean $=3.14 ;$ SD $=1.07)$ & & \\
\hline $\mathrm{CO} 1$ & The best form of policing in Nigeria is the traditional system such as OPC, Arewa, Egbesu, etc. & 3.21 & 1.38 \\
\hline $\mathrm{CO} 2$ & Nigeria police is a conception of the British colonialist & 3.05 & 1.34 \\
\hline $\mathrm{CO} 3$ & Nigeria police should have been scrapped after independence in favour of the traditional police & 3.32 & 1.42 \\
\hline $\mathrm{CO} 4$ & I see Nigeria police as alien to the Nigerian value system & 3.30 & 1.37 \\
\hline $\mathrm{CO} 5$ & I would rather trust the traditional police than the Nigeria Police & 2.96 & 1.43 \\
\hline $\mathrm{CO6}$ & I would rather obey the traditional police than the Nigeria Police & 3.01 & 1.45 \\
\hline
\end{tabular}

Note: Responses ranged from strongly disagree (1) to strongly agree (5). 
Table 4 Bivariate correlations between scales.

\begin{tabular}{|c|c|c|c|c|c|c|c|c|c|c|}
\hline & & $\mathbf{1}$ & 2 & 3 & 4 & 5 & 6 & 7 & 8 & 9 \\
\hline (1) & Compliance with the Law & 1 & .069 & -.002 & $395 * *$ & $.413 * *$ & $.449 * *$ & .037 & -.070 & -.041 \\
\hline (2) & Police Legitimacy & & 1 & .008 & .069 & $.142 * *$ & $.085^{*}$ & -.068 & -.019 & $-.098^{*}$ \\
\hline (3) & Dull Compulsion & & & 1 & -.017 & -.065 & .037 & $.291 * *$ & $.375^{* *}$ & -.020 \\
\hline (4) & Procedural Justice & & & & 1 & $.494 * *$ & $.108 * *$ & $-.139 * *$ & $-.244 * *$ & -.028 \\
\hline (5) & Police Effectiveness & & & & & 1 & $.171 * *$ & $-.248 * *$ & $-.325^{* *}$ & $-.106^{* *}$ \\
\hline (6) & Experience of Abuse & & & & & & 1 & $.154 * *$ & .077 & -.011 \\
\hline (7) & Predatory Policing & & & & & & & 1 & $.446 * *$ & .043 \\
\hline (8) & Police Corruption & & & & & & & & 1 & $110 * *$ \\
\hline (9) & Police Colonial Origin & & & & & & & & & 1 \\
\hline
\end{tabular}

* Statistical significant at $\mathrm{p}<.05$
** Statistical significant at $\mathrm{p}<.01$

\section{Multiple Regression Analyses}

Three multiple regression analyses were undertaken to address the aims of this study. Table 5 presents results for a multiple regression analysis showing predictors of dull compulsion and police legitimacy. Table 6 presents results for a multiple regression showing predictors of selfreported compliance with the law.

Table 5 Predicting dull compulsion and police legitimacy

\begin{tabular}{|c|c|c|c|c|}
\hline \multirow[b]{2}{*}{ Variable } & \multicolumn{2}{|c|}{ Dull Compulsion } & \multicolumn{2}{|c|}{ Police Legitimacy } \\
\hline & $\beta$ & $t$ & $\boldsymbol{\beta}$ & $\bar{t}$ \\
\hline Age & .01 & .26 & $-.15 * *$ & -2.96 \\
\hline Gender & -.00 & -.11 & .02 & .49 \\
\hline Marital status & .00 & .03 & $.15 * *$ & 2.94 \\
\hline Education & .01 & .29 & -.00 & -.08 \\
\hline Religion & .03 & .82 & -.03 & -.69 \\
\hline Ethnicity & -.01 & -.13 & .00 & .05 \\
\hline Predatory Policing & $.17 * * *$ & 3.81 & -.07 & -1.52 \\
\hline Police Corruption & $.34 * * *$ & 7.63 & .04 & .89 \\
\hline Experience of Abuse & -.03 & -.78 & .08 & 1.87 \\
\hline Colonial Origin & -.05 & -1.36 & -.07 & -1.68 \\
\hline Police Effectiveness & .06 & 1.30 & $.12 *$ & 2.38 \\
\hline Procedural Justice & .06 & 1.44 & .00 & .06 \\
\hline $\mathbf{R}$ & .41 & & .24 & \\
\hline $\mathbf{R}^{2}$ & .17 & & .06 & \\
\hline $\mathbf{F}$ & $9.62 * * *$ & & $2.91 * * *$ & \\
\hline
\end{tabular}

Note: Statistical significance at ${ }^{*} \mathrm{p}<.05 ; * * \mathrm{p}<.005 ; * * * \mathrm{p}<.001$. 
Turning to Table 5 first, six demographic variables (age, gender, marital status, education, religion and ethnicity) and six other scales were entered into the first regression model predicting dull compulstion. Individually, two independent variables - perceived predatory policing $(\beta=.17 ; p<.001)$ and perceived police corruption $(\beta=.34 ; p<.001)-$ were significant predictors of expressed dull compulsion. This indicates that those who perceived police as predatory and corrupt were more likely to pragmatically acquiesce to police (i.e., express dull compulsion).

From the second column of Table 5 with police legitimacy as the outcome variable, it can be seen that two of the demographic variables - age $(\beta=-.15 ; p<.005)$ and marital status $(\beta=.15 ; p<.005)$ significantly predicted police legitimacy perceptions. This indicates that younger and single participants are more likely to perceive police as legitimate. Importantly, police effectiveness $(\beta=.12 ; p<.05)$ was a significant predictor of police legitimacy. Unlike most existing studies in the West, procedural justice was not a significant predictor of public perceptions of police legitimacy in Nigeria.

The findings imply that for people to defer to or ascribe legitimacy to the police in Nigeria, the age and marital status of people is important. So too are their perceptions of police effectiveness. Here, instrumental factors, not normative factors, appear to dominate Nigerian's evaluations of the legitimacy of Nigerian police. However, it is important to note that only $6 \%$ of the overall variation in perceptions of police legitimacy was explained by all the variables included in this regression model. This value is very small when compared to values typically reported in Western studies. The implication of this is that even though perceived police effectiveness was found to be significant in this study, it explains relatively little variation in Nigerians' perceptions of police legitimacy. This suggests that public perceptions of police 
legitimacy in Nigeria are likely to be influenced by other factors not accounted for in this analysis.

Table 6 Predicting self-reported compliance with the law

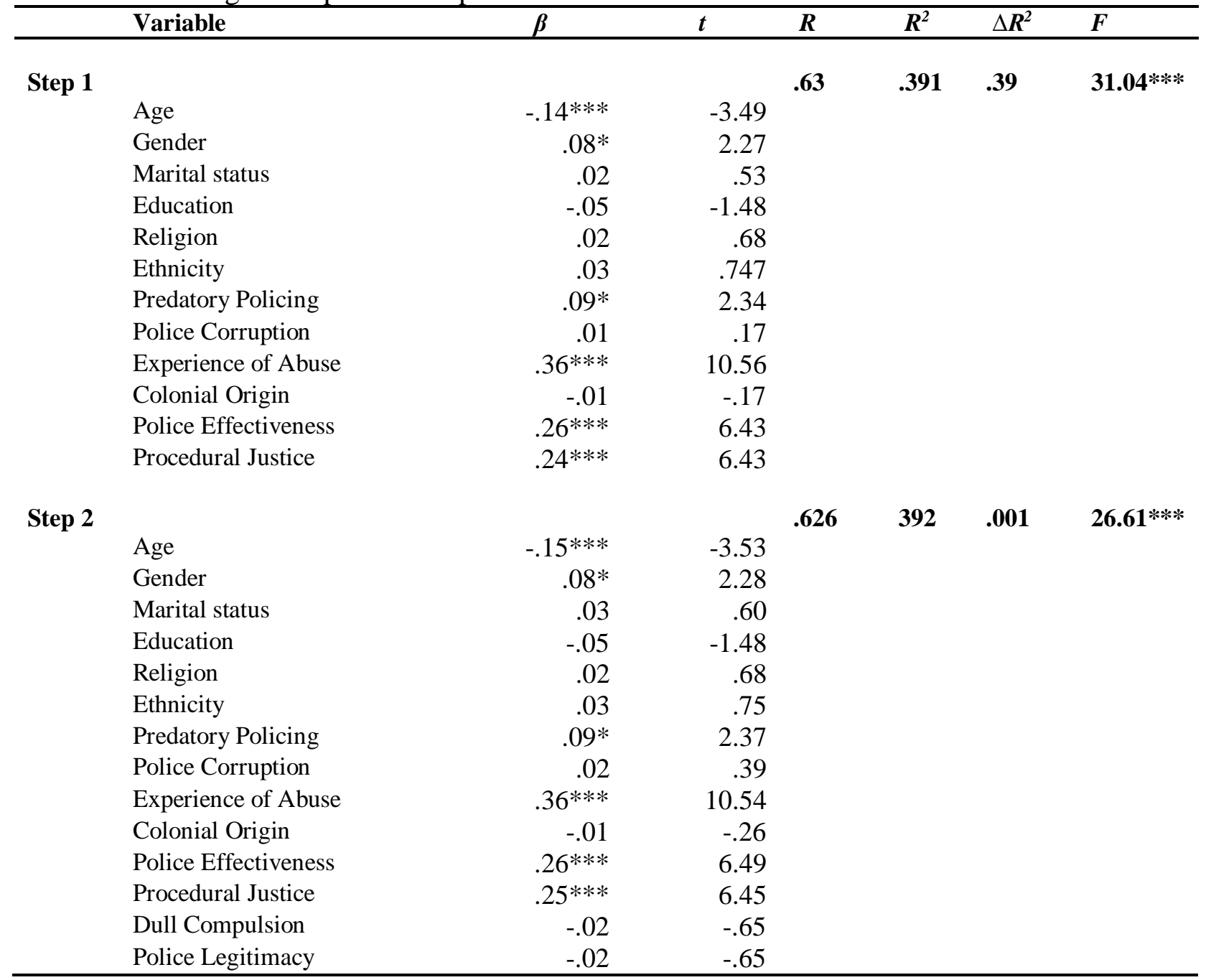

Note: Statistical significance at $* \mathrm{p}<.05 ; * * * \mathrm{p}<.001$

Table 6 presents fourteen variables as predictors of voluntary compliance with the law in Nigeria. Individually, six variables including age $(\beta=-.15 ; p<.001)$, gender $(\beta=.08 ; p<$ $.05)$, perceived predatory policing $(\beta=.09 ; p<.05)$, experience of police abuse $(\beta=.36 ; p<$ $.001)$, perceived police effectiveness $(\beta=.26 ; p<.001)$, and perceived procedural justice $(\beta$ 
$=.24 ; p<.001)$ were significant predictors of self-reported voluntary compliance with the law. It is important to note that the addition of two important scales at Step 2 (i.e., dull compulsion and police legitimacy) did not make any significant contribution in the model. In summary, the results indicate that those who had experienced police abuse, those who perceived police as predatory, effective in crime control, and procedurally fair, were more likely to say they would comply with the law. In addition, younger and female respondents were more likely to comply with the law in Nigeria.

\section{DISCUSSION}

The aims of the current study were twofold: 1) to examine factors that explain Nigerians' perceptions of police legitimacy and feelings of dull compulsion; and 2) to examine whether perceptions of police legitimacy or dull compulsion motivate people to comply with the law. Western studies consistently find that if police are perceived as effective and procedurally just, the public will view them as more legitimate. Western studies also show that procedural justice tends to be the most important predictor of police legitimacy evaluations and that legitimacy judgments are strongly associated with self-reported compliance behaviour (e.g., Hough, Jackson, \& Bradford, 2013; Jackson et al., 2012; Reisig et al., 2014; Tom R Tyler, 1997).

In the current study, we found a significant relationship between perceptions of police effectiveness and perceptions of police legitimacy. In fact, police effectiveness was the primary predictor of legitimacy in our study; if police were seen to be more effective in dealing with crime and disorder they were viewed as more legitimate. Importantly, procedural justice was not associated with police legitimacy perceptions in Nigeria. Like Tankebe's (2009) findings from Ghana, our findings suggest that procedural justice may not be the primary driver of police legitimacy perceptions in all settings or contexts. But why might Nigerians place more emphasis on police effectiveness than procedural justice when forming judgements about 
police legitimacy? One explanation may be due to the strong emphasis on a crime control model of policing in Nigeria and the fact that crime is on the increase (see Agbiboa, 2013; Hills, 2012; Smith, 2004, 2007). Nigerian public expects the police to guarantee the safety of lives and properties in their neighbourhood. If this expectation is not met, people are likely to perceive police as ineffective and hence question their legitimacy. Given increasing crime levels in Nigeria, priority may therefore be given to factors related to police effectiveness rather than to whether police treat citizens fairly. In other words, of what benefit is a police force that treats people fairly but lacks the ability to protect its citizens in the face of incessant crime?

The current study represented the first attempt to test empirically whether dull compulsion was associated with self-reported compliance behaviour. Hence, we were uncertain at the commencement of the study about what to expect from the findings. It is interesting to note that in the current study neither dull compulsion nor legitimacy were associated with citizens' self-reported compliance. The fact that legitimacy was unrelated to compliance was unexpected. Previous studies in the West consistently find that if police are viewed as legitimate then citizens will be more inclined to say they will comply with the law (e.g., Hough et al., 2013; Jackson et al., 2012; Reisig et al., 2014; Tom R Tyler, 1997). This was not so in Nigeria. The findings therefore challenge the view that police legitimacy is crucial for ensuring citizens comply with laws. The findings also negate Tankebe (2009) assumption that people in countries with widespread police corruption comply with the law due to expressions of dull compulsion.

If legitimacy and dull compulsion do not predict compliance, what factors are important for explaining citizens' compliance behaviour in Nigeria? Surprisingly, perceptions of both procedural justice and police effectiveness were important predictors of self-reported compliance in Nigeria. Perceiving police as predatory and having personally experienced 
police abuse also appears important, with the latter variable being the most important predictor of self-reported compliance in Nigeria. That is, the more abuse people have personally experienced at the hands of police, the more they say they will comply with the law. It seems, then, that Nigerians comply with laws because they are wary of being caught breaking the law because they know, if caught, they might be physically abused by the police.

These findings show that willingness to comply with the law might come at a price, and unfortunately, it may be the forceful subjugation and abuse of the people that drives them to comply with the law. In essence, it appears that general and specific deterrence play an important role in ensuring compliance with laws in Nigeria. It can also be implied from these findings that voluntary compliance with the law also rests on how Nigerians interpret the concept of fair procedures or what they see as being fair, even when experiencing police abuse.

Although the results of the current study showed no significant relationship between expressions of dull compulsion and voluntarily compliance with the law, they do suggest a situation in which people's response to police 'misconduct' points toward pragmatic acquiescence to the power of police. In particular, the results showed that there are statistically significant relationships between perceptions of predatory policing, perceptions of police corruption, and expressions of dull compulsion (see Table 4). Likewise, those who experienced police abuse personally and who viewed police as predatory said they were more likely to comply with the law (see Table 6). The association of these variables together may indicate the presence of perceived individual helplessness in the presence of a corrupt police power. Importantly, the results contradict Tankebe (2009) suggestion that expressions of dull compulsion, rather than perceived police legitimacy, may be responsible for people's selfreported willingness to comply with the law in developing and postcolonial societies. Of course the dull compulsion measure utilised in the current study may have been inadequate to capture 
this concept. Hence, this requires further testing in future studies. Unravelling the potential connection between pragmatic acquiescence to police power and compliance behaviour is integral to our understanding of policing in Nigeria.

\section{CONCLUSION}

This study makes a number of contributions to the policing literature by reaffirming the results of prior research work both in the developed and developing contexts. Importantly, the research outcomes provide evidence that a perception of procedural justice is not the dominant factor Nigerians consider in forming their evaluations about the legitimacy of police. However, this study corroborates that procedural justice operates much the same way in Nigeria as it does in other developed contexts in fostering self-reported compliance with the law, but perhaps in a less dominant manner. The implications of the results indicate that despite the widespread importance of perceived procedural justice in predicting perceptions of police legitimacy in developed western contexts, it would be naïve to conclude that procedural justice is the only source of legitimacy upon which police should rely. That is, the idea that procedural justice is the panacea to solving legitimacy deficits in all societies may not cater, after all, to all contexts and policing situations.

In conclusion, this study is the first to test empirically Tankebe's (2009) suggestion that compliance with the law in dictatorial societies is not garnered through the legitimacy of police, but rather through a dull compulsion to comply with the law. We found no direct support for this assertion. In fact, there was no evidence that either legitimacy or dull compulsion predicted compliance behaviour in Nigeria. But there was some suggestion that Nigerians do comply out of endemic helplessness borne from personal experiences of police brutality. Specifically, personal experiences with police abuse and viewing police as predatory seems important for explaining why people comply with laws in Nigeria. What this study indicates is that there is 
a need to reconsider that not all practicable theories or findings from developed western societies will hold traction in a developing context. There is a need to reconsider the approach of transporting western theories to understand policing in Africa and other developing contexts. Moreover, it reinforces the need to develop a more nuanced understanding of what constitutes legitimacy or promotes law-abiding behaviour in different contexts. 


\section{REFERENCES}

Agbiboa, D. E. (2013). Corruption and economic crime in Nigeria: Social and economic perspectives. African Security Review, 22(1), 47-66.

Agbiboa, D. E. (2015). "Policing Is Not Work: It Is Stealing by Force": Corrupt Policing and Related Abuses in Everyday Nigeria. Africa Today, 62(2), 94-126.

Ahire, P. T. (1991). Imperial Policing: The Emergence and Role of the Police in Colonial Nigeria, 1860-1960. Milton Keynes: Open University Press

Ahire, P. T. (1993). Native Authority Police in Nigeria: End of an Era. Policing Nigeria: Past, Present and Future.

Akinlabi, O. M. (2011). Legitimacy, Corruption and Delinquency: A Study of Adolescents' Perceptions and Behaviour in Nigeria. Retrieved from Cambridge:

Akinlabi, O. M. (2013). Predatory Policing in Nigeria: Public Experiences of Police Corruption, Brutality and its Implication on Police Legitimacy. Paper presented at the Australia and New Zealand Society of Criminology (ANZSOC) Conference, Brisbane Convention and Exhibition Centre, Australia. http://www.anzsoc.org/cmsconferences/2013.phps

Akinlabi, O. M. (2015). Young people, procedural justice and police legitimacy in Nigeria. Policing and Society, 1-20.

Akinlabi, O. M. (2016). Do the Police Really Protect and Serve the Public? Police Deviance and Public Cynicism towards the Law. Criminology and Criminal Justice, 1-17. doi: $10.1177 / 1748895816659906$

Alemika, E. O. (1993). Colonialism, state and policing in Nigeria. Crime, Law and Social Change, 20, 187-219.

Alemika, E. O. (2010). History, Context and Crises of the Police in Nigeria Repositioning the Nigeria Police to Meet the Challenges of the Policing a Democratic Society in the Twenty-First Century and Beyond. Uyo, Akwa Ibom, Nigeria: Unpublished Presentation at the Biennial Retreat of the Nigeria Police Service Commission.

Baker, B. (2010). Security in Post-Conflict Africa: The Role of Nonstate Policing. Boca Raton, FL: CRC Press.

Beetham, D. (1991). Max Weber and the legitimacy of the modern State. Analyse \& Kritik, $13(1), 34-45$.

Bradford, B., Huq, A., Jackson, J., \& Roberts, B. (2014). What price fairness when security is at stake? Police legitimacy in South Africa. Regulation \& governance, 8(4), 246-268.

Carrabine, E. (2004). Power, Resistance, and Discourse: A Genealogy of the Strangeways Prison Riot. Aldershot, England: Ashgate Pub Ltd.

Carrabine, E. (2005). Prison riots, social order and the problem of legitimacy. British Journal of Criminology, 45(6), 896-913.

Carter, H. M. (1981). Prospects for the Administration of Justice in Nigeria: Courts, Police, and Politics. Journal of Opinion, 11(1/2), 29-34.

Davidson, B., Buah, F. K., \& Ade-Ajayi, J. F. (1966). A History of West Africa to the Nineteenth Century. New York: Doubleday \& Co. Inc.

Gerber, T. P., \& Mendelson, S. E. (2008). Public experiences of police violence and corruption in contemporary Russia: a case of predatory policing? Law \& Society Review, 42(1), 144.

Hills, A. (2012). Lost in translation: why Nigeria's police don't implement democratic reforms. International affairs, 88(4), 739-755.

Hinds, L., \& Murphy, K. (2007). Public Satisfaction with Police: Using Procedural Justice to Improve Police Legitimacy. Australian and New Zealand Journal of Criminology, $40(1), 27-43$. 
Hough, M., Jackson, J., \& Bradford, B. (2013). Legitimacy, trust and compliance: An empirical test of procedural justice theory using the European Social Survey: Legitimacy and Criminal Justice: An International Exploration, Oxford: Oxford University Press.

Human Rights Watch, H. (2010, August 17). 'Everyone's in on the Game': Corruption and Human Rights Abuses by the Nigeria Police Force. Human Rights Watch Web site. Retrieved from http://www.hrw.org/en/news/2010/08/17/nigeria-corruption-fuelingpolice-abuses

Jackson, J., Bradford, B., Hough, M., Myhill, A., Quinton, P., \& Tyler, T. R. (2012). Why do People Comply with the Law? Legitimacy and the Influence of Legal Institutions. British Journal of Criminology, 52, 1051-1071.

Johnson, D., Maguire, E. R., \& Kuhns, J. B. (2014). Public perceptions of the legitimacy of the law and legal authorities: Evidence from the Caribbean. Law \& Society Review, 48(4), 947-978.

Kochel, T. R. (2012). Can police legitimacy promote collective efficacy? Justice Quarterly, 29(3), 384-419.

Mazerolle, L., Sargeant, E., Cherney, A., Bennett, S., Murphy, K., Antrobus, E., \& Martin, P. (2014). Procedural justice and legitimacy in policing. Cham, Switzerland: Springer.

Murphy, K., Bradford, B., \& Jackson, J. (2015). Motivating Compliance Behavior Among Offenders: Procedural Justice or Deterrence? Criminal Justice and Behavior, 0093854815611166.

Murphy, K., Murphy, B., \& Mearns, M. (2010). 'The 2009 Crime, Safety and Policing in Australia Survey': Survey Methodology and Preliminary Findings: Citeseer.

Murphy, K., Tyler, T. R., \& Curtis, A. (2009). Nurturing Regulatory Compliance: Is Procedural Justice Effective when People Question the Legitimacy of the Law? Regulation and Governance, 3, 1-26.

Ohonbamu, O. (1972). The Dilemma of Police Organization under a Federal System: The Nigerian Example. The Nigerian Law Journal, 6, 73-87.

Okafor, N. (2007). Law Enforcement in Postcolonial Africa: Interfacing Indigenous and English Policing in Nigeria. International Police Executive Symposium, A Working Paper Number 7.

Oluwaniyi, O. O. (2011). Police and the institution of corruption in Nigeria. Policing and Society, 21(1), 67-83. doi:10.1080/10439463.2010.541245

Onoge, O. F. (1993). Social Conflicts and Crime Control in Colonial Nigeria Policing Nigeria: Past, Present and Future. Lagos: Malthouse Press Ltd

Onyeozili, E. C. (1998). An Examination of Social Control and Policing in Nigeria: A Theoretical and Evaluative Analysis. (Unpublished $\mathrm{PhD}$ Thesis).

Onyeozili, E. C. (2005). Obstacles to Effective Policing in Nigeria. African Journal of Criminology and Justice Studies, 1(1), 32-54.

Otu, N. N. (1999). Colonialism and the criminal justice system in Nigeria. International Journal of Comparative and Applied Criminal Justice, 23(2), 293-306.

Reisig, M. D., Tankebe, J., \& Mesko, G. (2014). Compliance with the law in Slovenia: The role of procedural justice and police legitimacy. European Journal on Criminal Policy and Research, 20(2), 259-276.

Sargeant, E., Murphy, K., \& Cherney, A. (2014). Ethnicity, trust and cooperation with police: Testing the dominance of the process-based model. European Journal of Criminology, $11(4), 500-524$.

Smith, D. J. (2004). The Bakassi Boys: vigilantism, violence, and political imagination in Nigeria. Cultural Anthropology, 429-455.

Smith, D. J. (2007). A Culture of Corruption: Everyday Deception and Popular Discontent in Nigeria. New Jersey: Princeton University Press. 
Sparks, R., \& Bottoms, A. E. (2007). Legitimacy and Imprisonment Revisited: Some Notes on the Problem of Order Ten Years After. In J. Byrne, F. Taxman, \& D. Hummer (Eds.), The culture of prison violence (pp. 91-104). Boston, MA: Pearson.

Sunshine, J., \& Tyler, T. R. (2003). The Role of Procedural Justice and Legitimacy in Shaping Public Support for Policing. Law \& Society Review, 37(3), 513-548. doi:10.1111/15405893.3703002

Tamuno, T. N. (1970). The Police in Modern Nigeria, 1861-1965: Origins, Development and Role. Ibadan: Ibadan University Press.

Tankebe, J. (2009). Public Cooperation with the Police in Ghana: Does Procedural Fairness Matter? Journal of Criminology, 47, 1265 - 1293.

Tankebe, J. (2010). Public Confidence in the Police Testing the Effects of Public Experiences of Police Corruption in Ghana. British Journal of Criminology, 50(2), 296-319.

Tankebe, J. (2013). Viewing Things Differently: The Dimensions of Public Perceptions of Police Legitimacy. Criminology, 51(1), 103-135. doi:10.1111/j.17459125.2012.00291.x

Tyler, T. R. (1990). Why People Obey the Law. New Haven, CT: Yale University Press.

Tyler, T. R. (1997). Procedural fairness and compliance with the law. Swiss Journal of Economics and Statistics, 133, 219-240.

Tyler, T. R. (2006). Why People Obey the Law. Princeton: Princeton University Press.

Tyler, T. R., \& Fagan, J. (2008). Why do people cooperate with the police? Ohio State Journal of Criminal Law, 6, 231-275.

Vaaseh, G. A., \& Ehinmore, O. M. (2011). Ethnic Politics and Conflicts in Nigeria's First Republic: The Misuse of Native Administrative Police Forces (NAPFS) and the Tiv Riots of Central Nigeria,1960-1964. Canadian Social Science, 7(3), 214-222.

Weitzer, R. J. (2010). Race and Policing in Different Ecological Contexts. In S. K. Rice \& M. D. White (Eds.), Race, ethnicity, and policing: New and essential readings (pp. 118139). New York: New York University Press. 